\title{
PENGARUH METODE BERMAIN TERHADAP KETERAMPILAN MEMBACA PERMULAAN SISWA KELAS I SD INPRES BATEGULUNG
}

\author{
Syamsu Wahid, Sulfasyah, Rubianto. \\ Pendidikan Guru Sekolah Dasar, Fakultas Keguruan dan Ilmu Pendidikan, \\ Universitas Muhammadiyah Makassar \\ Iqramsyar34@gmail.com
}

\begin{abstract}
ABSTRAK
Jenis penelitian ini adalah penelitian pra-eksperimen bentuk Pre Test Post Test Design yaitu sebuah eksperimen yang dalam pelaksanaannya hanya melibatkan satu kelas sebagai kelas eksperimen tanpa adanya kelas pembanding (kelas kontrol) yang bertujuan untuk mengetahui pengaruh metode bermain terhadap keterampilan membaca permulaan siswa kelas 1 SD Inpres Bategulung tahun ajaran 2016/2017. Satuan eksperimen dalam penelitian ini adalah murid Kelas 1 sebanyak 15 orang. Penelitian dilaksanakan selama 5 kali pertemuan. Keberhasilan proses pembelajaran ditinjau dari aspek, yaitu: ketercapaian ketuntasan hasil belajar Bahasa Indonesia murid secara klasikal, aktivitas siswa dalam pembelajaran Bahasa Indonesia. Pembelajaran dikatakan berhasil jika aspek di atas terpenuhi. Teknik pengumpulan data yang digunakan adalah data skor perolehan hasil membaca permulaan siswa yang dikumpulkan dengan menggunakan tes membaca, data tentang aktivitas siswa dalam pembelajaran Bahasa Indonesia dikumpulkan dengan menggunakan lembar observasi aktivitas belajar siswa. Hasil analisis statistik deskriptif penggunaan metode bermain terhadap keterampilan membaca permulaan siswa positif, keterampilan membaca permulaan siswa dengan menggunakan metode bermain menunjukkkan hasil belajar yang lebih baik dari pada sebelum diterapkan metode bermain. Hasil analisis statistik inferensial menggunakan rumus uji $t$, diketahui bahwa nilai $t_{\text {Hitung }}$ yang diperoleh adalah 7,5 dengan frekuensi $d b=15-1=14$, pada taraf signifikansi $5 \%$ diperoleh $\mathrm{t}_{\text {Tabel }}=2,14$. Jadi, $\mathrm{t}_{\text {Hitung }}>\mathrm{t}_{\text {tabel }}$ atau hipotesis nol $\left(\mathrm{H}_{0}\right)$ ditolak dan hipotesis alternative $\left(\mathrm{H}_{1}\right)$ diterima. Hal ini membuktikan bahwa ada pengaruh dalam menerapkan metode bermain terhadap keterampilan membaca permulaan siswa kelas $1 \mathrm{SD}$ Inpres Bategulung.
\end{abstract}

Kata kunci: Pra-eksperimen, metode bermain; Membaca Permulaan 


\section{PENDAHULUAN}

Bahasa indonesia adalah salah bahasa yang mutlak dan wajib di berikan atau diajarkan kepada setiap warga negara indonesia serta dapat di kembangkan secara luas ke negara lain.dalam dunia pembelajaran atau dunia pendidikan bahasa indonesia harus lebih awal di berikan kepada para murid di sekolah sebagai dasar pengembangan atau langkah awal dalam mengembangkan keterampilan siswa dalam keterampilan membaca.

Akhadiah (1992:33) mengemukakan bahwa "kemampuan membaca merupakan salah satu kunci keberhasilan siswa dalam meraih kemajuan". Keberhasilan belajar siswa dalam mengikuti proses kegiatan belajar mengajar di sekolah sangat ditentukan oleh penguasaan kemampuan membaca. oleh karena itu, keterampilan membaca harus dikuasai oleh siswa SD karena kemampuan membaca sangat berkaitan dengan seluruh proses belajar mengajar.

Menurut Pestalozzi (Djuanda 2006: 86) mengatakan bahwa bermain mempunyai nilai-nilai untuk mengembangkan harmoni antara jiwa dan raga. Hal ini sejalan dengan pendapat Bennet (Djuanda2006: 87) yang pernah mengadakan penelitian pada guru waktu murid bermain para guru mengatakan bahwa para siswa mengungkapkan perilaku yang mencerminkan kebutuhan batin mereka serta proses intelektual yang mendalam.

Fungsi bermain tidak saja meningkatkan perkembangan kognitif dan sosial tetapi juga mengembangkan bahasa emosi, disiplin, kreatifitas, dan perkembangan fisik anak. Melalui bermain perkembangan sosial anak juga terkembangkan misalnya sikap sosial, belajar berkomunikasi, mengorganisasikan peran, dan lebih menghargai orang lain. Melalui bermain anak dapat mengandalikan emosinya, menyalurkan keinginannya dan rasa percaya diri. Anak juga dapat menerapkan disiplin dengan menunggu giliran atau mentaati peraturan. Dengan bermain guru mendapatkan gambaran yang lengkap tentang keseluruhan diri siswa, misalnya seorang guru menyatakan bahwa perilaku para siswa pada waktu bermain dapat mengungkapkan sifat-sifat siswa tersebut yang berlangsung di rumahnya.

Berdasarkan uraian di atas rumusan masalah dalam penelitian ini adalah apakah terdapat pengaruh metode bermain terhadap keterampilan membaca permulaan siswa 
kelas 1 SD Inpres Bategulung?. Tujuan penelitian ini adalah untuk mengetahui apakah terdapat pengaruh metode bermain terhadap keterampilan membaca permulaan siswa kelas 1 SD Inpres Bategulung.

\section{Pengertian Membaca}

Membaca pada hakikatnya adalah suatu yang rumit yang melibatkan banyak hal, tidak hanya sekedar melafalkan tulisan, tetapi juga melibatkan aktifitas visual, berpikir, psikolinguistik dan metakognitif. Sebagai proses visual membaca merupakan proses menerjemahkan simbol tulis (huruf) ke dalam kata-kata lisan. Sebagai suatu proses berpikir membaca mencakup aktivitas pengenalan kata, pemahaman literal, interprestasi, membaca kritis dan pemahaman kreatif. Crawley dan Mountain (Rahim 2007: 2) mengatakan bahwa pengenalan kata bisa berupa aktifitas membaca kata-kata dengan menggunakan kamus.

Menurut Farr (Dalman, 2013:5) mengemukakan, reading is the heart of education yang artinya membaca merupakan jantung pendidikan. Dalam hal ini, orang yang sering membaca, pendidikannya akan maju dan ia akan memiliki wawasan yang luas. Tentu saja hasil membacanya itu akan menjadi skemata baginya.

Tampubolon (2008:56) mengatakan bahwa "membaca adalah aktivitas fisik dan mental". Melalui membaca informasi dan pengetahuan yang berguna bagi kehidupan dapat diperoleh. Inilah motivasi pokok yang dapat mendorong tumbuh dan berkembangnya minat membaca.

Safi `ie (1999: 5-7) mengatakan bahwa konsep dasar membaca yaitu:

1. Membaca pada hakikatnya adalah pengembangan keterampilan, mulai dari keterampilan memahami kata-kata, kalimat-kalimat, paragraf-paragraf dalam bacaan sampai dengan memahami secara kritis dan evaluatif seluruh isi bacaan.

2. Membaca pada hakikatnya adalah kegiatan visual berupa serangkaian gerakan mata dalam mengikuti baris-baris tulisan, pemutusan penglihatan pada kata dan kelompok kata, melihat ulang kata dan kelompok kata untuk memperoleh pemahaman terhadap bacaan.

3. Membaca pada hakikatnya adalah kegiatan memahami dan mengamati kata-kata yang tertulis, memberikan makna terhadap kata-kata tersebut berdasarkan pengetahuan dan pengalaman yang telah dipunyai. 
4. Membaca adalah suatu proses berpikir yang terjadi melalui proses mempersepsi dan memahami informasi serta memberikan makna terhadap bacaan.

5. Membaca pada hakikatnya adalah proses mengolah informasi dalam membaca terjadi proses pengolahan informasi yang dilaksanakan oleh pembaca dengan menggunakan informasi dalam bacaan dan pengetahuan serta pengalaman yang telah dipunyai sebelumnya yang relevan dengan informasi tersebut

6. Membaca pada hakikatnya adalah proses menghubungkan tulisan dengan bunyinya sesuai dengan sistem tulisan yang digunakan.

7. Membaca pada hakikatnya adalah kemampuan mengantisipasi makna yang terdapat pada baris-baris dalam tulisan. Kegiatan membaca bukan hanya kegiatan bersifat mekanis saja, melainkan merupakan kegiatan menangkap maksud dari kelompok-kelompok kata yang membawa makna.

\section{Pengertian Bermain}

Bermain merupakan salah satu fenomena yang paling alamiah dan luas dalam kehidupan anak, terdapat insting bermain pada setiap anak serta kebutuhan melakukannya dalam suatu pola yang khusus guna melibatkan dalam suatu kegiatan yang membantu proses kematangan anak. Dari berbagai penelitian Seto (Djuanda 2006: 86) terungkap bahwa bermain dapat dikembangkan menjadi semacam alat untuk mengatualisasikan potensi kritis pada diri anak, mempersiapkan fungsi intelektual dan aspek emosi dan sosialnya. Dengan demikian, bermain berkembang bukan hanya menjadi sarana yang dapat dinikmati dan menyenangkan saja tetapi juga bersifat mendidik.

Kesenangan anak- anak bermain dapat dipakai sebagai kesempatan untuk belajar hal-hal yang kongkret, sehingga daya cipta imajinasi dan kreativitas anak berkembang. Semiawan(2002:21) menyatakan bahwa"bermain bagi anak memiliki nilai dan ciri yang penting dalam kemajuan perkembangan kehidupan sehari-hari". Bermain adalah cara yang paling efektif pada usia sekolah dasar baik di bidang akademik maupun aspek fisik, sosial dan emosional.

Sudjana (1997:24) menyatakan bahwa Metode pembelajaran Bahasa Indonesia dengan permaianan yaitu suatu pembelajaran yang dilakukan dengan mengaktifkan siswa menggunakan alat peraga atau sesuai dengan kreatifitas guru sehingga 
menghasilkan pembelajaran yang menarik dan menyenangkan agar tujuan pembelajaran dapat tercapai secara optimal.

Melalui situasi bermain anak diharapkan mendapatkan pemahaman yang mendalam terhadap objek-objek dan memiliki keterampilan khusus dalam mengamati dan memperoleh materi, serta agar anak mendapat makna spiritual yang disimbolkan materi dan kegiatan- kegiatan tersebut. Bermain ini akhirnya dapat digunakan guru sebagai wahana atau teknik pembelajaran untuk membentuk pemahaman melalui kegiatan bermain peran atau dengan menggunakan berbagai media yang tersedia.

Dengan demikian, bermain dalam kaitannya dengan pendidikan ialah sebagai wahana pembelajaran dalam bentuk permainan sesuatu yang bermakna dalam menggambarkan pesan, suasana, mengembangkan pengetahuan dan keterampilan yang bernilai bagi anak dalam membuahkan pengalaman belajar.

\section{METODE PENELITIAN}

Jenis penelitian ini adalah penelitian eksperimen, yaitu metode penelitian yang digunakan untuk mencari pengaruh perlakuan tertentu terhadap yang lain dalam kondisi yang terkendalikan (Sugiyono 2006: 72). Desain penelitian ini merupakan penelitian pre-eksperimental designs jenis One-Group Pretes-Posttest Design. Dalam penelitian ini hasil perlakuan dapat diketahui lebih akurat, karena dapat membandingkan dengan keadaan sebelum diberi perlakuan (treatment).

Populasi dalam penelitian ini adalah seluruh siswa kelas I SD Inpres Bategulung yang berjumlah 15 orang. Dalam penelitian ini sampelnya terdiri dari semua populasi kelas 1 SD Inpres Bategulung yang berjumlah 15 siswa, siswa laki-laki 6 orang dan siswa perempuan 9 orang. Tehnik analisis data dalam penilitian ini adalah Analisis Data Statistik Inferensial dan pengujian hipotesis.

\section{HASIL PENELITIAN DAN PEMBAHASAN}

\section{Hasil Pretest Bahasa Indonesia Siswa Kelas 1 SD Inpres Bategulung.}

Pada pemberian pretest sebelum menerapkan metode bermain, siswa belum mampu menyebutkan berbagai macam huruf sebanyak $60 \%$, belum mampu menyusun huruf menjadi sebuah kata yang mempunyai arti atau makna sebanyak $60 \%$, maka 
diperoleh data yang dikumpulkan melalui instrumen tes sehingga dapat diketahui kemampuan membaca permulaan sebelum dilaksanakan metode bermain berupa nilai dari siswa kelas 1 SD Inpres Bategulung.

Untuk mencari mean (rata-rata) nilai pre-test dari siswa kelas 1 SD Inpres Bategulung dapat dilihat melalui tabel di bawah ini:

Tabel 1. Perhitungan untuk mencari mean ( rata - rata ) nilai pretest

\begin{tabular}{|c|c|c|}
\hline$X$ & $F$ & $F . X$ \\
\hline 55 & 4 & 220 \\
\hline 60 & 5 & 300 \\
\hline 65 & 2 & 130 \\
\hline 70 & 1 & 70 \\
\hline 75 & 1 & 75 \\
\hline 80 & 1 & 80 \\
\hline 90 & 1 & 90 \\
\hline Jumlah & 15 & 965 \\
\hline
\end{tabular}

Dari data di atas dapat diketahui bahwa nilai dari $\Sigma f x=965$, sedangkan nilai dari $\mathrm{N}$ sendiri adalah 15 . Oleh karena itu, dapat diperoleh nilai rata-rata (mean) sebagai berikut:

$$
\begin{aligned}
\bar{x} & =\frac{\sum_{i=1}^{k} f x_{i}}{n} \\
& =\frac{965}{15} \\
& =64,33
\end{aligned}
$$

Dari hasil perhitungan di atas maka diperoleh nilai rata-rata dari hasil belajar murid kelas 1 SD Inpres Bategulung sebelum penerapan metode bermain yaitu 64,33. Adapun dikategorikan pada pedoman Departemen pendidikan dan kebudayaan (Depdikbud), maka keterangan murid dapat dilihat pada tabel berikut:

Tabel 2. Tingkat keterampilan membaca Pretest

\begin{tabular}{|l|l|l|l|l|}
\hline No & Interval & Frekuensi & Persentase & Kategori Hasil \\
\hline
\end{tabular}




\begin{tabular}{|c|c|c|c|c|}
\hline & & & $(\%)$ & Belajar \\
\hline 1 & $0-55$ & 4 & 26,66 & Sangat Rendah \\
2 & $56-65$ & 7 & 46,66 & Rendah \\
3 & $66-75$ & 2 & 13,33 & Sedang \\
4 & $76-85$ & 1 & 6,66 & Tinggi \\
5 & $86-100$ & 1 & 6,66 & Sangat tinggi \\
\hline \multicolumn{2}{|l}{ Jumlah } & 15 & 100 & \\
\hline
\end{tabular}

Berdasarkan data yang dapat dilihat pada tabel di atas maka dapat disimpulkan bahwa hasil belajar murid pada tahap pretest dengan menggunakan instrumen test dikategorikan sangat rendah yaitu 26,66\%, rendah 46,66\%, sedang 13,33\%, tinggi $6,66 \%$ dan sangat tingggi berada pada presentase 6,66\%. Melihat dari hasil presentase yang ada dapat dikatakan bahwa tingkat keterampilan membaca permulaan murid sebelum diterapkan metode bermain tergolong rendah.

Tabel 3 Deskripsi Ketuntasan Hasil Belajar Bahasa Indonesia

\begin{tabular}{|c|c|c|c|}
\hline Skor & Kategorisasi & Frekuensi & $\%$ \\
\hline $0 \leq x<65$ & Tidak tuntas & 9 & 60 \\
\hline $65 \leq x \leq 100$ & Tuntas & 6 & 40 \\
\hline \multicolumn{2}{|c|}{ Jumlah } & 15 & 100 \\
\hline
\end{tabular}

Apabila Tabel 3 dikaitkan dengan indikator kriteria ketuntasan hasil belajar murid yang ditentukan oleh peneliti yaitu jika jumlah murid yang mencapai atau melebihi nilai KKM (65) $\geq 75 \%$, sehingga dapat disimpulkan bahwa keterampilan membaca permulaan murid Kelas 1 SD Inpres Bategulung belum memenuhi kriteria ketuntasan hasil belajar secara klasikal karena siswa yang tuntas hanya $40 \% \leq 75 \%$.

\section{Deskripsi Hasil Belajar (Posttest) Bahasa Indonesia Siswa Kelas 1 SD Inpres Bategulung setelah diterapkan metode bermain}

Selama penelitian berlangsung terjadi perubahan motivasi belajar setelah diberikan perlakuan. Perlakuan tersebut berupa memberikan metode bermain melompat sambil menyebutkan berbagai macam huruf yang di tunjukkan kepada siswa dalam proses pembelajaran membaca permulaan, siswa bermain sambil belajar 
menyusun sebuah huruf menjadi sebuah kata yang mempunyai makna atau arti. Perubahan tersebut berupa hasil belajar yang datanya diperoleh setelah diberikan posttest. Jenis posttest yang diberikan kepada siswa,mulai dari pengenalan huruf, penyusunan huruf sesuai dengan abjad, serta penyusunan berbagai huruf menjadi sebuah kata yang dapat dipahami oleh siswa yang mempunyai arti.

Untuk mencari mean (rata-rata) nilai post-test dari murid kelas 1 SD Inpres Bategulung :

Tabel 4. Perhitungan untuk mencari mean (rata-rata) nilai post-tes

\begin{tabular}{|c|c|c|}
\hline$X$ & $F$ & $F . X$ \\
\hline 60 & 3 & 180 \\
\hline 70 & 4 & 280 \\
\hline 75 & 1 & 75 \\
\hline 80 & 1 & 80 \\
\hline 85 & 3 & 255 \\
\hline 90 & 1 & 90 \\
\hline 95 & 2 & 190 \\
\hline Jumlah & 15 & 1150 \\
\hline
\end{tabular}

Dari data hasil post-test di atas dapat diketahui bahwa nilai dari $\sum f x=1150$ dan nilai dari $\mathrm{N}$ sendiri adalah 15 . Kemudian dapat diperoleh nilai rata-rata (mean) sebagai berikut:

$$
\begin{aligned}
\bar{x} & =\frac{\sum_{i=1}^{k} f x_{i}}{n} \\
& =\frac{1150}{15} \\
& =76,66
\end{aligned}
$$

Dari hasil perhitungan di atas maka diperoleh nilai rata-rata dari hasil belajar murid kelas 1 SD Inpres Bategulung setelah penerapan metode bermain yaitu 76,66 dari skor ideal 100. Adapun di kategorikan pada pedoman Departemen pendidikan dan kebudayaan (Depdikbud), maka keterangan murid dapat dilihat pada tabel berikut:

Tabel 5. Tingkat keterampilan membaca Post-test 


\begin{tabular}{|c|c|c|c|c|}
\hline No & Interval & Frekuensi & $\begin{array}{c}\text { Persentase } \\
(\%)\end{array}$ & Kategori Hasil Belajar \\
\hline 1 & $0-55$ & - & 0,00 & Sangat Rendah \\
2 & $56-65$ & 3 & 20 & Rendah \\
3 & $66-75$ & 5 & 33,33 & Sedang \\
4 & $76-85$ & 4 & 26,66 & Tinggi \\
5 & $86-100$ & 3 & 20 & Sangat tinggi \\
\hline \multicolumn{2}{r|}{ Jumlah } & 15 & 100 & \\
\hline
\end{tabular}

Berdasarkan data yang dapat dilihat pada tabel di atas maka dapat disimpulkan bahwa hasil belajar siswa pada tahap post-test dengan menggunakan instrumen test dikategorikan sangat tinggi yaitu 20\%, tinggi 26,66\%, sedang 33,33\%, rendah 20\%, dan sangat rendah berada pada presentase 0,00\%. Melihat dari hasil presentase yang ada dapat dikatakan bahwa tingkat keterampilan siswa dalam membaca permulaan setelah diterapkan metode bermain tergolong tinggi.

Tabel 6 Deskripsi Ketuntasan Hasil Belajar Bahasa Indonesia

\begin{tabular}{|c|c|c|c|}
\hline Skor & Kategorisasi & Frekuensi & $\%$ \\
\hline $0 \leq x<65$ & Tidak tuntas & 3 & 20 \\
\hline $65 \leq \times \leq 100$ & Tuntas & 12 & 80 \\
\hline \multicolumn{2}{|r|}{ Jumlah } & 15 & 100 \\
\hline
\end{tabular}

Apabila Tabel 6 dikaitkan dengan indikator kriteria ketuntasan hasil belajar murid yang ditentukan oleh peneliti yaitu jika jumlah murid yang mencapai atau melebihi nilai KKM (65) $\geq 75 \%$, sehingga dapat disimpulkan bahwa keterampilan membaca permulaan siswa Kelas 1 SD Inpres Bategulung telah memenuhi kriteria ketuntasan hasil belajar secara klasikal karena siswa yang tuntas adalah $80 \%$. $\geq 75 \%$.

\section{Pengaruh Penerapan Metode Bermain pada Murid Kelas 1 SD Inpres Bategulung}

Sesuai dengan hipotesis penelitian yakni "ada pengaruh dalam menerapkan metode bermain terhadap keterampilan membaca permulaan siswa kelas 1 SD Inpres 
Bategulung", maka teknik yang digunakan untuk menguji hipotesis tersebut adalah teknik statistik inferensial dengan menggunakan uji-t.

Tabel 7. Analisis skor Pre-test dan Post-test

\begin{tabular}{|c|c|c|c|c|}
\hline No & $\mathrm{X} 1$ (Pre-test) & $\mathrm{X} 2$ (Post-test) & $\mathrm{d}=\mathrm{X} 2-\mathrm{X} 1$ & $\mathrm{~d}^{2}$ \\
\hline 1 & 55 & 60 & 5 & 25 \\
\hline 2 & 70 & 85 & 15 & 225 \\
\hline 3 & 55 & 60 & 5 & 25 \\
\hline 4 & 80 & 95 & 15 & 225 \\
\hline 5 & 75 & 90 & 15 & 225 \\
\hline 6 & 55 & 70 & 15 & 225 \\
\hline 7 & 60 & 70 & 10 & 100 \\
\hline 8 & 65 & 85 & 15 & 225 \\
\hline 9 & 90 & 95 & 5 & 25 \\
\hline 10 & 65 & 70 & 5 & 25 \\
\hline 11 & 60 & 85 & 25 & 625 \\
\hline 12 & 55 & 60 & 5 & 25 \\
\hline 13 & 60 & 80 & 20 & 400 \\
\hline 14 & 60 & 75 & 15 & 225 \\
\hline 15 & 60 & 70 & 10 & 100 \\
\hline & 965 & 1150 & 180 & 2700 \\
\hline
\end{tabular}

Langkah-langkah dalam pengujian hipotesis adalah sebagai berikut:

1. Mencari nilai "Md" dengan menggunakan rumus:

$$
\begin{aligned}
\text { Md } & =\frac{\sum d}{N} \\
& =\frac{180}{15} \\
& =12
\end{aligned}
$$

2. Mencari nilai " $\sum X^{2} d$ " dengan menggunakan rumus:

$$
\begin{aligned}
\sum X^{2} d & =\sum d^{2}-\frac{\left(\sum d\right)^{2}}{N} \\
& =2700-\frac{(180)^{2}}{15}
\end{aligned}
$$




$$
\begin{aligned}
& =2700-\frac{32400}{15} \\
& =2700-2160 \\
& =540
\end{aligned}
$$

3. Menentukan nilai $t_{\text {Hitung }}$

$$
\begin{aligned}
\mathrm{t} & =\frac{M d}{\sqrt{\frac{\sum X^{2} d}{N(N-1)}}} \\
\mathrm{t} & =\frac{12}{\sqrt{\frac{540}{15(15-1)}}} \\
\mathrm{t} & =\frac{12}{\sqrt{\frac{540}{210}}} \\
\mathrm{t} & =\frac{12}{\sqrt{2,57}} \\
\mathrm{t} & =\frac{12}{1,60} \\
\mathrm{t}=7,5 &
\end{aligned}
$$

4. Menentukan nilai $t_{\text {Tabel }}$

Untuk mencari $\mathrm{t}$ Tabel peneliti menggunakan tabel distribusi $\mathrm{t}$ dengan taraf signifikan $\alpha=0,05$ dan $d . b=N-1=15-1=14$ maka diperoleh $\mathrm{t}_{0,05}=$ 2,14 .

Setelah diperoleh $\mathrm{t}_{\text {Hitung }}=7,5$ dan $\mathrm{t}_{\text {Tabel }}=2,14$ maka diperoleh $\quad \mathrm{t}_{\text {Hitung }}>$ t Tabel atau 7,5 > 2,14. Sehingga dapat disimpulkan bahwa $\mathrm{H}_{0}$ ditolak dan $\mathrm{H}_{\mathrm{a}}$ diterima. Ini berarti bahwa ada pengaruh dalam menerapkan metode bermain terhadap keterampilan membaca permulaan siswa kelas 1 SD Inpres Bategulung.

Berdasarkan hasil pre-test, nilai rata-rata hasil belajar siswa 64,33 dengan kategori yakni sangat rendah yaitu 26,66\%, rendah 46,66\%, sedang 13,33\%, tinggi 6,66\% dan sangat tingggi berada pada presentase 6,66\%.. Melihat dari hasil presentase yang ada dapat dikatakan bahwa tingkat keterampilan membaca permulaan siswa sebelum diterapkan metode bermain tergolong rendah.

Selanjutnya nilai rata-rata hasil post-test adalah 76,66 jadi keterampilan siswa dalam membaca permulaan setelah diterapkan metode bermain mempunyai hasil belajar yang lebih baik dibanding dengan sebelum penerapan metode bermain. Selain itu persentasi kategori hasil belajar Bahasa Indonesia siswa juga meningkat yakni 
sangat tinggi yaitu 20\%, tinggi $26,66 \%$, sedang 33,33\%, rendah $20 \%$, dan sangat rendah berada pada presentase $0,00 \%$.

Berdasarkan hasil analisis statistik inferensial dengan menggunakan rumus uji t, dapat diketahui bahwa nilai thitung sebesar 7,5. Dengan frekuensi (dk) sebesar $15-1=$ 14 , pada taraf signifikansi $5 \%$ diperoleh $t_{\text {tabel }}=2,14$. Oleh karena $t_{\text {hitung }}>t_{\text {tabel }}$ pada taraf signifikansi 0,05 , maka hipotesis nol $\left(\mathrm{H}_{0}\right)$ ditolak dan hipotesis alternative $\left(\mathrm{H}_{\mathrm{a}}\right)$ diterima yang berarti bahwa ada pengaruh dalam menerapkan metode bermain terhadap keterampilan membaca permulaan.

Hasil analisis diatas yang menunjukkan adanya pengaruh penerapan metode bermain terhadap keterampilan membaca permulaan sejalan dengan hasil observasi yang dilakukan. Berdasarkan hasil observasi terdapat perubahan pada siswa yaitu pada awal kegiatan pembelajaran ada beberapa siswa yang melakukan kegiatan lain atau bersikap cuek selama pembelajaran berlangsung. Hal ini dapat dilihat pada pertemuan pertama murid yang melakukan kegiatan lain sebanyak 2 orang, sedangkan pada pertemuan terakhir hanya 1 murid yang melakukan kegiatan lain pada saat permainan berlangsung. Pada awal pertemuan, hanya sedikit murid yang aktif mengikuti pembelajaran. Akan tetapi sejalan dengan diterapkannya metode bermain murid mulai aktif pada setiap pertemuan.

Hasil observasi menunjukkan banyaknya jumlah murid yang menjawab pada saat diajukan pertanyaan dan murid yang mengajukan diri untuk melakukan kegiatan membaca. Murid juga mulai aktif dan percaya diri untuk menyampaikan perasaan dan pendapatnya setelah melakukan kegiatan permainan, mereka mengaku senang dan sangat menikmati permainan yang dilakukan sehingga termotivasi untuk mengikuti pelajaran. Proses pembelajaran yang menyenangkan membuat murid tidak lagi keluar masuk pada saat pembelajaran berlangsung dan tidak lagi merasa bosan ataupun tertekan ketika mengikuti proses pembelajaran di kelas.

Berdasarkan hasil analisis statistik deskriptif dan statistik inferensial yang diperoleh serta hasil observasi yang telah dilakukan, dapat disimpulkan bahwa ada pengaruh dalam menerapkan metode bermain terhadap keterampilan membaca permulaan siswa kelas 1 SD Inpres Bategulung. 
Sesuai dengan hasil penelitian tersebut dapat diperkuat dengan hasil penelitian yang dilakukan oleh peneliti sebelumnya Dewi ( 2013 ), menyatakan bahwa kemampuan membaca permulaan kelompok eksperimen tergolong tinggi dengan ratarata 18,29. Kemampuan membaca permulaan kelompok kontrol tergolong sedang dengan rata-rata 11,34 . Terdapat perbedaan yang signifikan kemampuan membaca permulaan siswa antara siswa yang dibelajarkan dengan pembelajaran tematik berbantuan permainan meloncat bulatan kata dan siswa yang dibelajarkan dengan model pembelajaran konvensional (thit $>$ ttab, thit $=8,27$ dan ttab $=1,980$ ). Hal ini berarti pembelajaran tematik berbantuan permainan meloncat bulatan kata berpengaruh terhadap kemampuan membaca permulaan.

Berdasarkan penelitian yang di lakukan oleh peneliti serta penguatan penilitian yang di kuatkan oleh penelitian sebelumnya, maka peneliti dapat menarik kesimpulan bahwa pengaruh metode bermain terhadap keterampilan membaca permulaan pada siswa kelas 1 sangat berpengaruh besar terhadap keterampilan membaca permulaan, pengaruh tersebut dapat di lihat dari nilai rata - rata yang di dapatkan siswa sebelum menerapkan metode bermain sebesar 64,33 dan sesudah

menerapkan metode bermain sebesar 76,66.

\section{SIMPULAN DAN SARAN}

Simpulan yang lebih rinci berkaitan pelaksanaan pembelajaran membaca permulaan dengan metode bermain pada siswa kelas 1 SD Inpres Bategulung sebagai berikut : (1) Berdasarkan data yang diperoleh dapat disimpulkan bahwa secara umum keterampilan membaca permulaan siswa kelas 1 SD Inpres Bategulung sebelum penerapan metode bermain dikategorikan rendah. Hal ini ditunjukkan dari perolehan persentase hasil belajar siswa yaitu sangat rendah $26,66 \%$, rendah $46,66 \%$, sedang $13,33 \%$, tinggi $6,66 \%$ dan sangat tingggi berada pada presentase 6,66\%. (2) Berdasarkan data yang diperoleh dapat disimpulkan bahwa sescara umum metode bermain berpengaruh terhadap keterampilan membaca permulaan siswa kelas 1 SD Inpres Bategulung dapat dilihat dari perolehan persentase yaitu sangat tinggi 20\%, tinggi 26,66\%, sedang 33,33\%, rendah 20\%, dan sangat rendah berada pada presentase 0,00\%. (3) Berdasarkan uji hipotesis yang telah dilakukan dapat disimpulkan bahwa penerapan metode bermain 
berpengaruh terhadap keterampilan membaca permulaan setelah diperoleh $t_{\text {Hitung }}=7,5$ dan $\mathrm{t}_{\text {Tabel }}=2,14$ maka diperoleh $\mathrm{t}_{\text {Hitung }}>\mathrm{t}_{\text {Tabel }}$ atau 7,5 $>2,14$.

Berdasarkan temuan yang berkaitan hasil penelitian penerapan metode bermain yang mempengaruhi keterampilan membaca permulaan siswa kelas 1 SD Inpres Bategulung, maka dikemukakan beberapa saran sebagai berikut: (1) Kepada para pendidik khususnya guru SD Inpres Bategulung, disarankan menerapkan metode bermain untuk membangkitkan minat dan motivasi siswa untuk belajar. (2) Kepada Peneliti, diharapkan mampu mengembangkan metode bermain ini dengan menerapkan pada materi lain untuk mengetahui apakah pada materi lain cocok dengan metode pembelajaran ini demi tercapainya tujuan yang diharapkan. (3) Kepada calon Peneliti, akan dapat mengembangkan dan memperkuat metode ini serta memperkuat hasil penelitian ini dengan cara mengkaji terlebih dahulu dan mampu mengadakan penelitian yang lebih sukses

\section{DAFTAR PUSTAKA}

Akhadiah, Sabarti. 1992. Bahasa Indonesia 2. Jakarta: Departemen Pendidikan dan Kebudayaan.

Anderson, R. C. (1972). Language Skills in Elementary Education. New York:Macmillan Publishing Co, Inc.

Budiasi dan Zuchdi. 1996/1997. Pendidikan Bahasa dan Satra Indonesia Dikelas Rendah. Jakarta: Depdikbud Direktorat Jenderal Pendidikan Tinggi Bagian Proyek Pengembangan Pendidikan Guru Sekolah Dasar

Dalman. 2013. Keterampilan Membaca. Bandar Lampung : Raja Grafindo Persada.

Departemen pendidikan dan kebudayaan. 1994/1995. Pengajaran Membaca. Jakarta: Depdikbud

Departemen pendidikan dan kebuyaan. 2003. Pengajaran Membaca. Jakarta: Departemen pendidikan dan kebuyaan

Djuanda Dadang. 2006. Pembelajaran Bahasa Indonesia Yang Komunikatif Dan Menyenangkan. Jakarta: Departemen pendidikan nasional 
Emzir. 2007. Metodologi Penelitian Pendidikan. Jakarta: PT. Rajagrafindo Persada.

Emzir. 2014. Metodologi Penelitian Pendidikan. Jakarta: PT. Rajagrafindo Persada.

Rahim, Farida. 2007. Pengajaran Membaca Di Sekolah Dasar. Jakarta: PT Bumi Aksara.

Sugiyono. 2006. Metode Penelitian Kuantitatif Kualitatif dan R\&D. Bandung: Alfabeta

Safi ie, Imam. 1999. Pengajaran Membaca Di Kelas-Kelas Awal Disekolah dasar. Malang: Depdiknas.

Semiawan, Conny R dkk. 2002. Belajar dan Pembelajaran Dalam Taraf Usia Dini. Jakarta: PT Prenhallindo.

Sudjana, Nana. 1997. Media Pengajaran. Bandung : Remaja Rosdakarya

Tampubolon, DP. 2008. Teknik Membaca Efektif dan Efisien. Bandung : Angkasa Bandung.

Tarigan, Henry Guntur. 2007. Membaca Sebagai Suatu Keterampilan Berbahasa. Bandung: Angkasa bandung.

Vacca, Jo Anne. 1991. Reading and Learning to Read. New York: Harper Collins Publisher. 